\title{
INCIDENCE OF ACUTE TRAUMA ON HAND AND WRIST: A RETROSPECTIVE STUDY
}

\section{INCIDÊNCIA DE TRAUMAS AGUDOS NA MÃO E NO PUNHO: ESTUDO RETROSPECTIVO}

\author{
Giovanna Damm Raphael Junqueira ${ }^{1}$, André Luiz Machado lima ${ }^{2}$, Robison Bon ${ }^{1}$, Joelmar César de Almeida ${ }^{1}$, Rafael Souza Ribeiro ${ }^{2}$, \\ LEANDRO AZEVEDO DE FIGUEIREDO ${ }^{1,2}$
}

1. Orthopedics and Traumatology Service, Santa Casa de Misericórdia de Vitória Hospital, Vitória, ES, Brazil.

2. Hand Group, Orthopedics and Traumatology Service, Hospital Estadual Doutor Jayme dos Santos Neves, Serra, ES, Brazil.

\section{ABSTRACT}

Objectives: A retrospective statistical data gathering of wrist and hand complaints assisted over two years in the orthopedic emergency department of a regional referral hospital, seeking to know the profile of these patients. Methods: Information obtained by analysis of 31.356 orthopedic visits from May 2013 to April 2015, of which 6.754 related to hand complaints and/ or wrist, at the Hospital Estadual Doutor Jayme dos Santos Neves (HDJSN) and analyzed by IBM SPSS Statistics software version 21. Results: The data revealed that the average age was $37,5 \pm 15,7$ years and the male gender was predominant $(60,72 \%)$. Bruises $(52,58 \%)$ and fractures $(30,49 \%)$ were the most common diagnoses. Conclusion: The complaints of wrist and hand accounted for $21,44 \%$ of all orthopedic emergency room visits. Detailed data description and correct definition of the International Classification of Diseases (ICD-10) are needed to better define the epidemiological profile of patients seeking orthopedic emergency. Level of Evidence III, Retrospective Study.

Keywords: Hand injuries/epidemiology. Wrist injuries/epidemiology. Emergency medical services. Orthopedics.

\section{RESUMO}

Objetivos: Fazer um levantamento de dados estatísticos retrospectivos dos atendimentos de lesões de punho e mão, ao longo de dois anos no pronto-socorro ortopédico de um hospital de referência regional, visando conhecer o perfil desses pacientes. Métodos: Informações obtidas por análise de 31.356 atendimentos ortopédicos no Hospital Estadual Doutor Jayme dos Santos Neves (HDJSN) entre maio de 2013 e abril de 2015, dos quais 6.754 apresentaram lesões na mão e/ou punho. Os dados foram analisados pelo programa IBM SPSS Statistics versão 21. Resultados: Os dados revelaram que a média de idade foi de 37,5 \pm 15,7 anos, com predominância do sexo masculino (60,72\%). Contusões (52,58\%) e fraturas (30,49\%) foram os diagnósticos mais frequentes. Conclusão: As lesões do punho e da mão corresponderam a $21,44 \%$ do total de atendimentos ortopédicos de emergência. A descrição detalhada dos dados e a definição exata na Classificação Estatística Internacional de Doenças e Problemas Relacionados com a Saúde (CID-10) são necessárias para determinar melhor o perfil epidemiológico do paciente que procura a emergência ortopédica. Nível de Evidência III, Estudo Retrospectivo.

Descritores: Traumatismos da mão/epidemiologia. Traumatismos do punho/epidemiologia. Serviços médicos de emergência. Ortopedia.

Citation: Junqueira GD, Lima AL, Boni R, Almeida JC, Ribeiro RS, Figueiredo LA. Incidence of acute trauma on hand and wrist: a retrospective study. Acta Ortop Bras. [online]. 2017;25(6):287-90. Available from URL: http://www.scielo.br/aob.

\section{INTRODUCTION}

Acute traumas involving upper limb in the emergency room are common, however, they are little understood from an epidemiological perspective. ${ }^{1}$ The injuries that affect the distal extremity of the upper limb are considered a major social and public health problem both due to the physical and mental impact, as well as to high costs of initial treatment of its sequels. ${ }^{2,3}$ According to the National Eletronic Injury Surveillance System (NEISS), lacerations and fractures of the fingers and hands are the anatomical sites most affected in the work accidents attended in the American emergency services. ${ }^{1}$ It is estimated that approximately $11-20 \%$ of visits to emergency departments in the United States are due to injuries to the hands and wrists, making the epidemiological analysis of these lesions of paramount importance. ${ }^{3-5}$ It is known that the costs of falling productivity due to absence from work, in general, are more expensive than the treatment of the injury itself. ${ }^{3}$ When added, the costs of absence from work with medical and hospital expenses can reach an average of thirty thousand dollars per injury. ${ }^{6}$ The social and economic costs cannot be measured only by the social security aspect, for not expressing its real dimension. The issue becomes more important if we consider, for example, the cost of specialized medical care, with more complex procedures, the

All authors declare no potential conflict of interest related to this article.

Work conducted at the Orthopedics and Traumatology Service of Hospital Estadual Doutor Jayme dos Santos Neves, Serra, ES, Brazil. Correspondence: Rua Quinze de Novembro, 232/801, Praia da Costa, Vile Velha, ES, Brazil. 29101-055. giovannadamm@yahoo.com.br 
drop in production resulting from absenteeism and the functional reduction consequent to the possible sequelae. ${ }^{7}$ The purpose of this study is to evaluate the characteristics of the injuries as well as to calculate epidemiological estimates of the traumatic injuries that affect the hand and the wrist by means of a population sample of patients attended in the orthopedic emergency of a reference hospital in trauma during two years, in the state of Espírito Santo. The hand would be the terminal segment of the upper limb, continuation of the fist, ending distally with the fingers. Its proximal limit would be given by a horizontal plane that passes through the pisiforme and the scaphoid. Its skeleton would correspond to the second row of the carpus (trapezoid, trapezoid, capitate and hamato), metacarpal bones and phalanges. The first row (scaphoid, lunate, pyramidal and pisiform) along with the distal end of the radius and ulna would belong to the wrist region.

\section{MATERIALS AND METHODS}

This is a cross-sectional epidemiological study. All information was obtained by means of data collection in the medical records of the orthopedic emergency room, defining the complaints concerning the wrist and the hand. Trauma denominations in these regions were classified according to the International Code of Diseases (ICD-10) and individual assessment of medical records. The study will cover visits between May 2013 and April 2015.

All researches used as a bibliographic source were collected using search sites such as PubMed and ClinicalKey, using the keywords "injury", "wrist", "hand", "emergency", "epidemiology" and "trauma".

\section{Calculation of rate:}

The sample size was 6,767. The variables analyzed in the wrist and hand traumas were: gender, color, age, municipality of origin and affection.

The project of this research was approved by the Ethics Committee (CAAE 50648015.1.0000.5065) of the Superior School of Sciences of Santa Casa de Misericórdia de Vitória on March 29, 2016.

The program used in the analyzes was the IBM SPSS Statistics version 23.

The data characterization was performed through the observed frequency, percentage, minimum, maximum, mean and standard deviation. The Chi-square test verified the association between qualitative variables. To compare quantitative and qualitative variables, variance analysis (ANOVA) was used using Dunnett's multiple comparison test, since the variances were not homogeneous (Levene's test). The level of significance adopted in all analyzes was $5 \%$ with a 95\% confidence interval.

\section{RESULTS}

Between May 2013 and April 2015, there were 101,769 visits to the emergency room of the reference trauma hospital in the city, orthopedic visits were 31,718 , which is the specialty with the highest number of records, followed by the medical clinic, with 30,207 And general surgery, with 26,212.

Of the orthopedic visits, $21.6 \%$ were of complaints related to wrist and hand. Even though this number is relatively large, corresponding to around 282 calls per month, this number is known to be far from realistic. Many of the injuries of the wrist and hand give entry to the PS for other specialties (mainly of the general surgery), it is up to the orthopedist to respond only to the opinion requested by the surgeon, thus keeping the record of the service as general surgery. The present study showed that the orthopedic care of all the visits in the emergency room of the reference unit in trauma during the period evaluated corresponded to $31.2 \%$. (Table 1)
Among the orthopedic visits, $21.6 \%$ corresponded to the complaints due to complaints in the distal regions of the upper limb, demonstrated in this work by the wrist or hand. (Table 2)

The male gender corresponded to $60.7 \%$ of the total sample. The parda color obtained $46.3 \%$. The municipality of Serra was the one that presented the highest proportion of attendances with $90.7 \%$, in which, together with the other municipalities of Grande Vitória, in addition, they presented $97.8 \%$ of the origin of those served, $1.8 \%$ referring to other municipalities of the state and $0.5 \%$ to municipalities in other states. The monthly distribution of attendances maintained a similar absolute value, varying from 512 (December months) to 592 (October months). The minimum age was 7 years, maximum of 99 years, an average age of 37.5 years and standard deviation of \pm 15.7 years. (Table 3 )

Table 1. Orthopedic PS attendances.

\begin{tabular}{c|c|c}
\hline & $\mathbf{n}$ & $\%$ \\
\hline Orthopedic attendances & 31718 & 31.2 \\
\hline Other attendances & 70051 & 68.8 \\
\hline Total & 101769 & 100.0 \\
\hline Source: Data from PS records.
\end{tabular}

\begin{tabular}{c|c|c} 
Table 2. Wrist/hand complaints at the orthopedic PS. \\
\hline Wrist and hand complaints at the orthopedic PS & $\mathbf{n}$ & $\%$ \\
\hline Other orthopedic attendances & 2467 & 21.6 \\
\hline Total & 31355 & 78.4 \\
\hline
\end{tabular}

Fonte: Data from orthopedic PS records.

\begin{tabular}{|c|c|c|c|}
\hline & & $\mathrm{n}$ & $\%$ \\
\hline \multirow{2}{*}{ Gender } & Male & 4109 & 60.7 \\
\hline & Female & 2657 & 39.3 \\
\hline \multirow{5}{*}{ Color } & Pardo color & 3141 & 46.4 \\
\hline & White & 1440 & 21.3 \\
\hline & Black & 596 & 8.8 \\
\hline & Yellow/Indigene & 105 & 1.6 \\
\hline & No Information & 1485 & 21.9 \\
\hline \multirow{3}{*}{ Procedence } & Grande Vitória & 6616 & 97.8 \\
\hline & Other municipalities of ES & 119 & 1.8 \\
\hline & Outher States & 32 & 0.5 \\
\hline \multirow{12}{*}{$\begin{array}{l}\text { Monthly } \\
\text { Distribution }\end{array}$} & January & 564 & 8.3 \\
\hline & February & 529 & 7.8 \\
\hline & March & 591 & 8.7 \\
\hline & April & 524 & 7.7 \\
\hline & May & 576 & 8.5 \\
\hline & June & 556 & 8.2 \\
\hline & July & 576 & 8.5 \\
\hline & August & 589 & 8.7 \\
\hline & September & 589 & 8.7 \\
\hline & October & 592 & 8.7 \\
\hline & November & 569 & 8.4 \\
\hline & December & 512 & 7.6 \\
\hline \multirow{2}{*}{ Age } & Minimum & Maximum & Medium \\
\hline & 7.0 & 99.0 & $37.5 \pm 15.7$ \\
\hline
\end{tabular}

Source: Data from orthopedic PS records. 
Regarding the affection, Contusion (52.5\%) and Fracture / Dislocation (34.3\%) had higher percentages. (Table 4)

The topographic distribution of the complaints was done as follows: Fist (40.8\%), Fingers (32.0\%) and Hand (22.8\%). Regions that were not specified in the medical records accounted for $4.4 \%$ of complaints. (Table 5)

A significant association of gender with affection (value $/ p=0.000$ ) was observed, and the positive contribution to significance occurred in the male gender with amputation, short-blunt injury, fracture / dislocation, and infection. In the female gender, positive significance occurred with contusion, pain and tenosynovitis. (Figure 1)

The association between topographic distribution and tendinous lesions was significant ( $p$ value $=0.042$ ). The lesions, when they occurred in the central region of the Hand, had a statistically significant relationship with lesions of the flexor tendons. The extensor lesions were positively associated with wrist injuries. (Figure 2)

\begin{tabular}{c|c|c} 
Table 4. Affection. & $\mathbf{n}$ & $\%$ \\
\hline Contusion & 3555 & 52.5 \\
\hline Fracture/dislocation & 2322 & 34.3 \\
\hline Short injury content & 444 & 6.6 \\
\hline Pain & 268 & 4.0 \\
\hline Tenosynovitis & 68 & 1.0 \\
\hline Amputation & 60 & 0.9 \\
\hline Convalescence & 31 & 0.5 \\
\hline Infection & 19 & 0.3 \\
\hline Total & 6767 & 100.0
\end{tabular}

Source: Data from orthopedic PS records.

Table 5. Topographic Distribution of the complaints.

\begin{tabular}{c|c|c}
\hline & $\mathbf{n}$ & $\%$ \\
\hline Wrist & 2763 & 40.8 \\
\hline Finger & 2164 & 32.0 \\
\hline Hand & 1545 & 22.8 \\
\hline Not specified & 295 & 4.4 \\
\hline Total & 6767 & 100.0 \\
\hline
\end{tabular}

Source: Data from othopedic PS records.

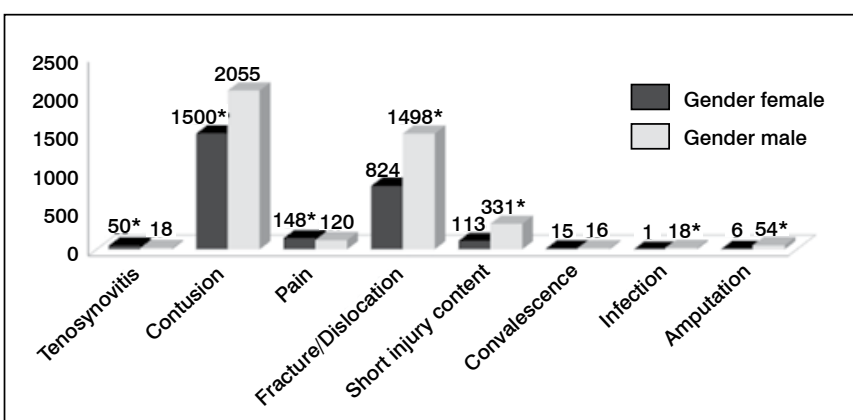

Source: Data from orthopedic emergency medical records. $\left.{ }^{*}\right)$ Statistical significance with $\mathrm{p}<0.000$

Figure 1. Disorders distributed by gender

\section{DISCUSSION}

In a study carried out in a university hospital in Ribeirão Preto, an analysis of the demand for emergency care was made in 2000, in which $27.6 \%$ corresponded to traumatic injuries involving the hands. ${ }^{6}$ Comparing the data obtained in this study with the literature, a strong predominance of the male gender was observed, with

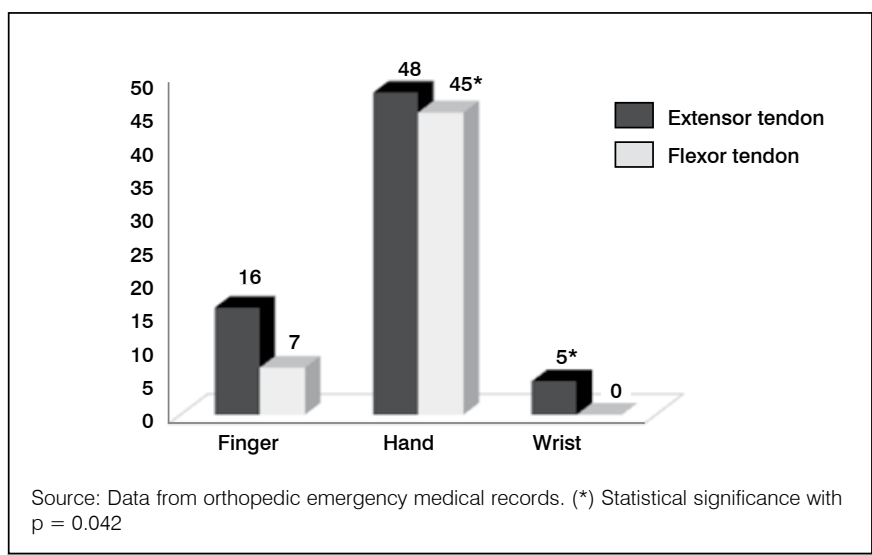

Figure 2. Tendon lesions according to topographic distribution.

$60.7 \%$. The data of this work presented results similar to those of Santos et al., ${ }^{8}$ Lopes $^{9}$ and Batista and Filgueira. ${ }^{10}$ The results found are in accordance with clinical experience, since men are more exposed to the risk of accidents, men in this way were responsible for more severe trauma records, such as amputation, short-blunt injury, fracture / dislocation and infection. On the other hand, women with $39.3 \%$ presented trauma considered milder, such as bruising, pain and tenosynovitis, and were statistically significant in both cases.

Accidents related to work tasks include, mainly, trauma and short bruised wounds on the hand, wrist and head, along with eye injuries. More intensive supervision in the use of protective equipment, more appropriate training in risk recognition, and safe working practices, including vehicle operation in the workplace, should be implemented to reduce work-related injuries. ${ }^{11}$

A 2009 consultation by the National System of Electronic Surveillance (NEISS) resulted in 92,601 records of upper extremity lesions treated in an emergency department in the US in 2009, which translates into an estimated total of $3,468,996$ such injuries that year. This corresponds to an incidence of 1,130 upper extremity lesions per 100,000 population per year. ${ }^{12}$

It was observed in this study that the incidence of flexor tendon injuries is greater when compared to extensor tendon injuries, most of them in the palm region, while extensor injuries affected the wrist region more, according to data from the literature. These lesions are usually associated with nerve damage. This is usually due to the hand-inflicted mechanism of trauma (often a knife or glass) that contains many delicate anatomical structures in the vicinity (superficial and deep flexor tendons, Joint ligament, arteries, and nerves) ${ }^{13}$ which are often not reported in the ICD-10 registry, so despite the effectiveness of the computerization of care, and the mandatory registration of ICD-10 to initiate care, many times the code may not correspond with actual patient injury.

This study raised the data of the emergency room visits during two years, stratifying the orthopedic care, and showing that more than $1 / 5$ of all care is related to hand and wrist trauma, with a great impact on the volume of care delivered for orthopedics. Based on this survey, other studies may be designed with a view to reducing trauma-related accidents on the hand, or even the need for specialized care by a hand surgeon in the initial evaluation of the patient.

\section{CONCLUSIONS}

Among all those attended, the male gender and the parda race had a higher prevalence. 
The most prevalent affections were contusion and fractures, with the hand being the region most affected.

Wrist and hand conditions accounted for $21.44 \%$ and all orthopedic care in the HDJSN emergency room between May 2013 and April 2015. Standardized information and registration methods are essential for data to be compared.
The results of previous studies in the area of hand and wrist injury may be comparable in some areas, but differences may occur due to variations in methods of data recording and classification. Better utilization of the international disease code (ICD-10), with accurate injury record, would facilitate and standardize the searches and documentation of patients with trauma to the wrist and hands.

AUTHORS' CONTRIBUTIONS: Each author made significant individual contributions to this manuscript. ALML (0000-0002-7702-9800)* and GDRJ (00000003-2891-1837)* were the main contributors in drafting the manuscript. RB (0000-0003-0685-7155)* and JCA (0000-0002-1338-6577)* performed the data collection and collected the clinical data. LAF (0000-0003-0120-5828)* and RSR (0000-0003-4779-3645)* evaluated the data for the statistical analysis. AL and GJ carried out the bibliographic research, reviewed the manuscript, and contributed to the intellectual concept of the study. ${ }^{*} \mathrm{ORCID}(\mathrm{Open}$ Researcher and Contributor ID).

\section{REFERENCES}

1. Sorock GS, Lombardi DA, Courtney TK, Cotnam JP, Mittleman MA. Epidemiology of occupational acute traumatic hand injuries: a literature review. Saf Sci. 2001;38(3):241-56.

2. Larsen CF, Mulder S, Johansen AM, Stam C. The epidemiology of hand injuries in The Netherlands and Denmark. Eur J Epidemiol. 2004;19(4):323-7.

3. de Putter CE, Selles RW, Polinder S, Panneman MJ, Hovius SE, van Beeck EF. Economic impact of hand and wrist injuries: health-care costs and productivity costs in a population-based study. J Bone Joint Surg Am. 2012;94(9):e56.

4. Brown TS, Hinojosa LS, Cline KE, Black SR, Jamieson MD, Starr AJ. Lack of Acute Hand Care in the Southwest United States. J Orthop Trauma. 2016;30(4):e129-31.

5. de Jong JP, Nguyen JT, Sonnema AJ, Nguyen EC, Amadio PC, Moran SL. The incidence of acute traumatic tendon injuries in the hand and wrist: a 10-year population-based study. Clin Orthop Surg. 2014;6(2):196-202.

6. Fonseca MCR, Mazzer N, Barbieri CH, Elui VMC. Traumas da mão: estudo retrospectivo. Rev Bras Ortop. 2006;41(5):181-6.

7. Ohara GH. Traumatismos complexos da mão - Princípios de tratamento. In: Pardin Junior AG, Freitas A. Traumatismos da mão. Rio de Janeiro: Medbook; 2008. p. 181-96.

8. Santos UP, Wünsch Filho V, do Carmo JC, Settimi MM, Urquiza SD, Henriques
CM. Epidemiological surveillance system for occupational accidents: experience in the northern area of the municipality of São Paulo (Brazil). Rev Saude Publica. 1990;24(4):286-93.

9. Lopes El. Aspectos sociais e econômicos dos traumatismos da mão. In: Pardini Júnior AG. Traumatismos da mão. 2a. ed. Rio de Janeiro: Medsi; 1992. p. 1-7.

10. Batista KT, Filgueira IC. Trauma complexo de mão: análise epidemiológica na Unidade de Cirurgia Plástica do Hospital Regional da Asa Norte/ FHDF/SeS Rev Saúde Dist Fed. 1997;8(4):25-31.

11. Aggazzotti G, Righi E, Patorno E, Fantuzzi G, Fabiani L, Giuliani AR, et al. Work-related injuries in young workers: an Italian multicentric epidemiological survey. Ann Ist Super Sanita. 2006;42(1):69-75.

12. Ootes D, Lambers KT, Ring DC. The epidemiology of upper extremity injuries presenting to the emergency department in the United States. Hand (N Y). 2012;7(1):18-22.

13. Miranda BH, Spilsbury ZP, Rosala-Hallas A, Cerovac S. Hand trauma: a prospective observational study reporting diagnostic concordance in emergency hand trauma which supports centralised service improvements. J Plast Reconstr Aesthet Surg. 2016;69(10):1397-402. 